\title{
DIMENSI RASA INGIN TAHU SISWA MELALUI PENDEKATAN SAINTIFIK BERBANTUAN ALAT PERGA PENJERNIHAN AIR
}

\author{
Duwi Nuvitalia $^{(1)}$, Siti Patonah ${ }^{(1)}$, Ernawati $S^{(1)}$ Khumaedi $^{(2)}$, Ani Rusilawati ${ }^{(2)}$ \\ Progdi Pendidikan Fisika Universitas PGRI Semarang ${ }^{(\mathbf{1})}$ \\ Progdi Pendidikan Fisika Universitas Negeri Semarang ${ }^{(2)}$ \\ nuvitalia@gmail.com
}

\begin{abstract}
ABSTRAK
Tujuan penelitian ini adalah untuk mengetahui dimensi Rasa Ingin Tahu siswa melalui pendekatan saintifik berbantuan alat peraga penjernihan air. Rasa ingin tahu merupakan salah satu dimensi dari sikap ilmiah yang terbagi menjadi beberapa indikator, diantaranya yaitu: antusias mencari jawaban, perhatian pada obyek yang diamati, antusias pada proyek sains dan menanyakan setiap langkah kegiatan. Jenis penelitian yang digunakan yaitu penelitian mixed method yang menggunakan metode pengumpulan data secara kualitatif dan kuantitatif. Instrumen dalam penelitian ini yaitu tes, lembar observasi dan lembar angket. Kesimpulan yang diperoleh yaitu pembelajaran IPA melalui pendekatan saintifik berbantuan alat peraga penjernihan air dapat diketahui sikap ilmiah pada dimensi rasa ingin tahu siswa meningkat.
\end{abstract}

Kata kunci : Rasa Ingin Tahu, pendekatan saintifik, alat peraga penjernihan air 


\section{PENDAHULUAN}

Rasa Ingin Tahu setiap orang memiliki kecenderungan yang berbeda. Bagi sebagian orang, Rasa ingin tahu bisa dianggap penting dan menjadi sebuah kebutuhan. Namun bagi sebagian lagi, Rasa Ingin Tahu ini hanya dianggap sebagai sikap biasa saja. Menurut Carin (dalam Ismawati et al, 2014: 23) rasa ingin tahu didefinisikan sebagai keinginan dan kebutuhan seseorang untuk memperoleh jawaban dari suatu pertanyaan atau hal-hal yang menimbulkan keingintahuan yang mendalam. Di dalam dunia pendidikan, Rasa Ingin Tahu harus terus dikembangkan agar dapat menjadi jembatan bagi siswa untuk memperoleh pengetahuan. Selain pengetahuan, terdapat ranah psikomotorik dan juga ranah sikap. Pendidikan IPA memiliki cakupan aspek yang lebih luas karena meliputi aspek kognitif, afektif dan psikomotor. Selama ini, pembelajaran IPA lebih cenderung menekankan pada aspek kognitif saja, sedangkan penilaian aspek sikap dan aspek psikomotorik pada pembelajaran IPA kurang diperhatikan. Hal ini mengakibatkan siswa kurang aktif dalam pembelajaran dan berimbas pada hasil belajar siswa yang rendah.

Salah satu penilaian aspek sikap, ditunjukkan dengan masalah yang sering dihadapi siswa yaitu keberanian berbicara. Lebih khusus yakni dalam hal mengemukakan pendapat karena kurangnya rasa ingin tahu siswa. Selain itu, untuk mendukung aspek psikomotorik, salah satunya yaitu dengan menggunakan alat peraga. Alat peraga didefinisikan sebagai alat bantu untuk mendidik atau mengajar agar konsep yang diajarkan oleh guru lebih mudah dimengerti siswa dan menjadi alat bantu yang dibuat oleh guru atau siswa dari bahan sederhana yang mudah didapat dari lingkungan sekitar (Widiyatmoko dan Pamelasari, 2012: 52).

Selain itu, penggunaan pendekatan saintifik merupakan implementasi kurikulum 2013 di dalam pembelajaran. Menurut Daryanto (2013) pembelajaran berbasis pendekatan saintifik hasil akhirnya adalah peningkatan dan keseimbangan antara kemampuan untuk menjadi manusia yang baik (soft skill) dan manusia yang memiliki kecakapan pengetahuan untuk hidup secara layak (hard skill) dari peserta didik yang meliputi aspek kompetensi sikap, pengetahuan, dan keterampilan. Tahapan-tahapan pada pendekatan saintifik dapat meningkatkan kemampuan peserta didik dalam hal mengamati, menanya, menalar, mencoba, mengkomunikasikan temuannya, sehingga berdampak positif terhadap kemampuan soft skill-nya.

Materi pokok pemisahan campuran merupakan materi IPA di kelas VII. Materi tersebut erat kaitannya dengan kehidupan sehari-hari siswa seperti peristiwa penjernihan air. Melalui alat peraga penjernihan air, pemahaman siswa diharapkan akan lebih baik. Penggunaan alat 
peraga penjernihan air ini merupakan aplikasi dari konsep pemisahan campuran. Di samping pemahaman yang lebih baik, sikap ilmiah siswa dapat terbentuk dengan digunakannya alat peraga. Untuk mengetahui dimensi rasa ingin tahu siswa melalui pendekatan saintifik berbantuan alat peraga penjernihan air

\section{METODE PENELITIAN}

\section{Jenis Penelitian}

Jenis penelitian yang digunakan yaitu penelitian mixed method yang menggunakan metode pengumpulan data secara kualitatif dan kuantitatif. Pengambilan data dilakukan secara simultan selama proses pengembangan alat peraga dan saat pembelajaran dengan pendekatan saintifik.

\section{Desain Penelitian}

Desain penelitian ini adalah Research and Development ( $\mathrm{R} \& \mathrm{D})$.

\section{Subjek Penelitian}

Subjek penelitian adalah siswa kelas VII MTs. Mathalibul Huda, Mlonggo Jepara.

\section{Instrumen Penelitian}

Instrumen yang digunakan untuk mengetahui aspek sikap ilmiah pada dimensi rasa ingin tahu siswa melalui pendekatan saintifik berbantuan alat peraga penjernihan air.

\section{HASIL DAN PEMBAHASAN}

Gagne menyebutkan bahwa dengan mengembangkan keterampilan Sains anak akan dibuat kreatif, dan mampu mempelajari sains di tingkat yang lebih tinggi dalam waktu yang lebih singkat (Sujarwanta, 2012: 75). Penggunaan keterampilan-keterampilan proses diharapkan siswa akan mampu menemukan serta dapat mengembangkan sendiri fakta dan konsep. Selain itu, siswa dapat menumbuhkan dan mengembangkan sikap dan nilai. Di dalam tujuan pembelajaran sains, dikatakan berhasil jika terdapat penilaian aspek kognitif, afektif, dan psikomotor. Aspek kognitif berkaitan dengan pengetahuan, pemahaman, dan keterampilan intelektual, aspek afektif berkaitan dengan sikap dan emosi, dan aspek psikomotor berkaitan dengan keterampilan. Aspek kognitif, afektif dan psikomotorik tersebut searah dengan hakikat sains yang harus ditinjau dari segi produk, proses, dan sikap ilmiah.

Menurut Suciati et al., (2014: 3) sikap ilmiah merupakan pendirian atau kecenderungan pola tindakan siswa terhadap suatu stimulus tertentu yang berorientasi pada ilmu pengetahuan dan metode ilmiah yang mencakup rasa ingin tahu, berpikir kritis, tekun, dan berdaya temu. Dimensi rasa ingin tahu memiliki beberapa indikator diantaranya meliputi indikator (1) antusias mencari jawaban, (2) perhatian pada objek yang diamati, (3) antusias pada proses sains dan (4) menanyakan setiap langkah kegiatan. 
Hasil penelitian didapatkan untuk klasifikasi data rasa ingin tahu dapat dilihat pada Tabel 1 berikut.

Tabel 1. Data Sikap Ilmiah pada Dimensi Rasa Ingin Tahu

\begin{tabular}{|c|c|c|c|c|c|c|c|c|}
\hline \multirow[b]{4}{*}{$\begin{array}{l}\text { Sebelum } \\
\text { perlakuan }\end{array}$} & \multicolumn{6}{|c|}{ Indikator Rasa Ingin Tahu } & & \\
\hline & \multicolumn{2}{|c|}{$\begin{array}{l}\text { antusias } \\
\text { mencari } \\
\text { jawaban }\end{array}$} & \multicolumn{2}{|c|}{$\begin{array}{c}\text { perhatian pada } \\
\text { objek yang } \\
\text { diamati }\end{array}$} & \multicolumn{2}{|c|}{$\begin{array}{c}\text { antusias pada } \\
\text { proses sains }\end{array}$} & \multicolumn{2}{|c|}{$\begin{array}{c}\text { menanyakan } \\
\text { setiap langkah } \\
\text { kegiatan }\end{array}$} \\
\hline & Eksp & Kont & Eksp & Kont & Eksp & Kont & Eksp & Kont \\
\hline & 72,5 & 38,3 & 71,7 & 45 & 72,5 & 39,2 & 66,7 & 49,2 \\
\hline $\begin{array}{l}\text { Setelah } \\
\text { perlakuan }\end{array}$ & 81,7 & 66,7 & 80 & 66,7 & 80,8 & 69,2 & 81,7 & 70 \\
\hline
\end{tabular}

Berdasarkan Tabel 1, terdapat peningkatan pada setiap dimensi/indikator baik dari kelas eksperimen maupun kelas kontrol. Perlakuan yang diberikan dalam pembelajaran IPA di kelas yaitu dengan menggunakan pendekatan saintifik berbatuan alat peraga penjernihan air. Pada indikator (1) antusias mencari jawaban, kemampuan awal kelas eksperimen dan kontrol berturut-turut 72,5 dan 38,3. Setelah mendapat perlakuan antusias mencari jawaban kelas eksperimen dan kontrol meningkat menjadi berturut-turut 81,7 dan 66,7. Pada indikator (2) yaitu indikator perhatian pada objek yang diamati kemampuan awal kelas eksperimen dan kontrol berturut-turut 71,7 dan 45. Setelah mendapat perlakuan kemampuan kelas eksperimen dan kontrol meningkat menjadi berturut-turut 80 dan 66,7.

Pada indikator (3) antusias pada proses sains, kemampuan awal kelas eksperimen dan kontrol berturut-turut 72,5 dan 39,5. Setelah mendapat perlakuan kemampuan kelas eksperimen dan kontrol meningkat menjadi berturut-turut 80,8 dan 69,2. Pada indikator (4) menanyakan setiap langkah kegiatan kemampuan awal kelas eksperimen dan kontrol berturutturut 66,7 dan 49,2. Setelah mendapat perlakuan kemampuan kelas eksperimen dan kontrol meningkat menjadi berturut-turut 81,7 dan 70. Berikut grafik perolehan untuk klasifikasi sikap ilmiah pada dimensi/indikator rasa ingin tahu kelas eksperimen dan kontrol dapat dilihat dalam Gambar 1.

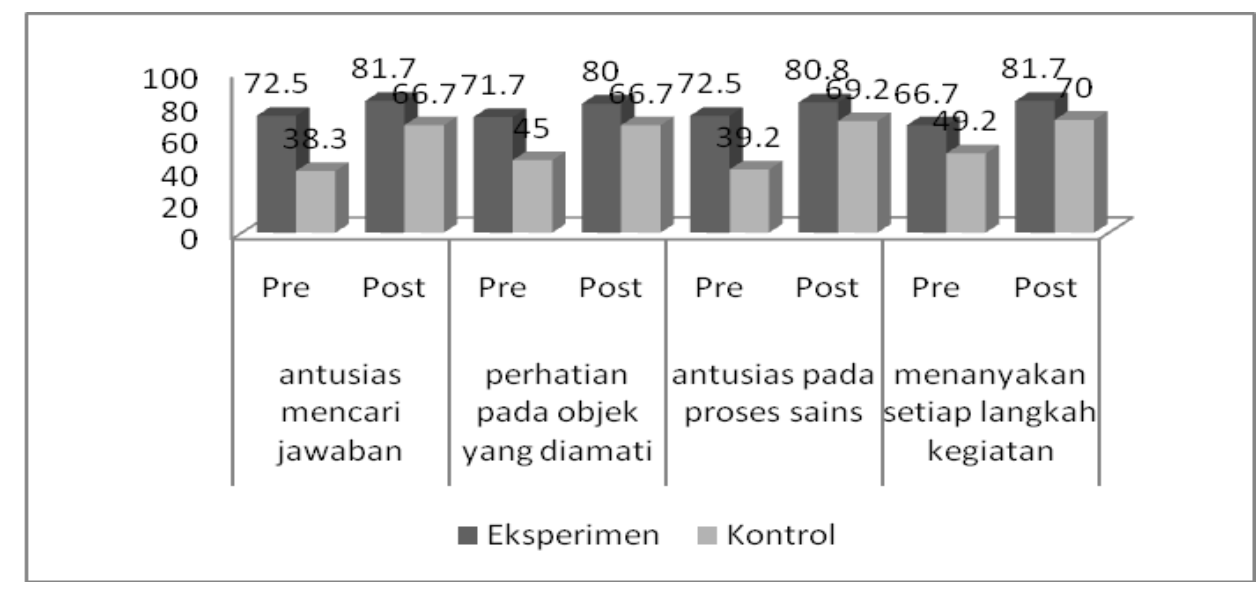


Gambar 1. Grafik Klasifikasi pada Indikator Rasa Ingin Tahu

Hasil penelitian tentang sikap ilmiah siswa pada dimensi rasa ingin tahu siswa, diketahui bahwa indikator antusias mencari jawaban merupakan satu indikator yang nilainya paling tinggi dari pada keempat indikator yang lain. Di dalam pembelajaran, hal ini terlihat pada keaktifan siswa pada saat pembelajaran materi pemisahan campuran dengan menggunakan media berupa alat peraga. Peran alat peraga di dalam pembelajaran sangat membantu siswa dalam memahami materi serta menjadikan siswa menjadi lebih aktif. Hal ini sesuai dengan pendapat Widyatmoko dan Pamelasari (2012: 52) bahwa alat peraga didefinisikan sebagai alat bantu untuk mendidik atau mengajar agar konsep yang diajarkan oleh guru lebih mudah dimengerti siswa dan menjadi alat bantu yang dibuat oleh guru atau siswa dari bahan sederhana yang mudah didapat dari lingkungan sekitar.

Selanjutnya pada indikator menanyakan setiap langkah kegiatan, siswa lebih terpacu untuk bertanya karena pada saat awal pembelajaran siswa melihat demonstrasi alat peraga penjernihan air yang dilakukan oleh guru. Melalui pengamatan, siswa belajar tentang penggunaan alat, bahan-bahan yang digunakan serta langkah kerja penggunaan alat. Dengan demikian, siswa menjadi lebih memahami materi dengan menggunakan alat peraga penjernihan air. Selain itu, sikap ilmiah siswa dalam pembelajaran dapat terlatih.

Pada indikator antusias pada proses sains, indikator ini ditunjukkan dengan siswa secara sistematis mengurutkan tahap-tahap percobaan sederhana penjernihan air. Pada indikator perhatian pada obyek yang diamati, siswa sangat fokus pada saat pembelajaran berlangsung. Adanya media berupa alat peraga penjernihan air ini membuat siswa belajar pada hal-hal yang bersifat nyata sehingga siswa mendapatkan hal baru untuk dipelajari.

Pencapaian dimensi rasa ingin tahu yang diperoleh siswa didukung pula dengan penggunaan model pembelajaran dengan menggunakan pendekatan saintifik. Menurut Daryanto (2014: 51) menyatakan bahwa pendekatan saintifik adalah proses pembelajaran yang dirancang sedemikian rupa agar peserta didik secara aktif mengkonstruksi konsep, hukum atau prinsip melalui tahapan-tahapan mengamati (untuk mengidentifikasi atau menemukan masalah), merumuskan masalah, mengajukan atau merumuskan hipotesis, mengumpulkan data dengan berbagai teknik, menganalisis data, menarik kesimpulan dan mengkomunikasikan konsep hukum atau prinsip yang ditemukan.

Selain penggunaan alat peraga, masing-masing indikator yang diuraikan dari sikap ilmiah dapat dicapai siswa dalam pembelajaran juga dikarenakan adanya penerapan 
pendekatan saintifik. Pendekatan saintifik adalah pendekatan pembelajaran yang berpusat pada peserta didik yang meliputi mengamati, menanya, mencoba, mengolah, menyajikan, menyimpulkan, dan mencipta untuk semua mata pelajaran (Permendikbud, 2013:166). Pada saat pembelajaran berlangsung, masing-masing tahapan pembelajaran mendukung terwujudnya sikap ilmiah pada dimensi atau indikator rasa ingin tahu.

Pada tahapan mengamati, siswa diajak untuk mengaati demonstrasi penggunaan alat peraga penjernihan air pada materi pokok pemisahan campuran yang terdapat di kelas VII semester gasal. Menurut Kosasih (2014: 74) kegiatan mengamati bertujuan untuk memperoleh gambaran umum dari suatu objek materi yang berkenaan dengan kompetensi dasar. Proses dalam kegiatan mengamati dapat berupa membaca sumber-sumber tertulis, mendengarkan informasi lisan, melihat gambar, menonton tayangan, dan menyaksikan fenomena alam, sosial, budaya. Selama pengamatan berlangsung, kegiatan bertanya (sebagai langkah pendekatan saintifik) dapat juga terjadi antara guru dan siswa. Hal ini sesuai dengan indikator rasa ingin tahu yaitu pada dimensi perhatian pada objek yang diamati, antusias pada proses sains serta menanyakan pada setiap langkah kegiatan. Hal senada juga dituliskan oleh Daryanto (2014: 64) bahwa dalam kegiatan menanya, guru membuka kesempatan secara luas kepada peserta didik untuk bertanya mengenai apa yang sudah dilihat, disimak, atau dibaca.

Pada tahapan mencoba di dalam pendekatan saintifik, siswa diminta untuk menggunakan alat peraga penjernihan air yang diawali dengan air keruh sebagai bahan percobaan. Pada proses pemisahan campuran dengan menggunakan alat peraga ini dapat melatih daya nalar siswa. Hal ini sesuai dengan langkah dalam pendekatan saintifik yaitu menalar. Selain itu, menurut Daryanto (2014: 78) untuk memeroleh hasil belajar yang nyata atau otentik, peserta didik harus mencoba atau melakukan percobaan, terutama untuk materi atau substansi yang sesuai. Dengan demikian, siswa dapat belajar dalam dunia nyata tentang apa yang dipelajari. Selain itu, siswa menjadi antusias dalam mencari jawaban serta antusias dalam proses sains dengan adanya media yakni alat peraga penjernihan air pada materi pemisahan campuran.

Proses pengolahan yang dimaksud dalam penelitian ini adalah pengolahan fisika, yaitu dengan memperhatikan sifat fisika pada zat-zat atau bahan dalam proses filtrasi menggunakan alat peraga penjernihan air. Bahan penyaring yang digunakan pada alat peraga penjernihan air terdiri dari kerikil, ijuk, pasir, arang dan batu zeolit. Masing-masing bahan memiliki peran dalam memisahkan campuran yang terkandung pada air yang disaring. Kegiatan penjernihan air ini sebagai aplikasi pemisahan campuran yang terdapat pada air keruh. Air keruh yang 
digunakan merupakan air yang sudah tercampur dengan bahan atau zat lain yang kemudian karena melalui proses penyaringan maka air keruh akan tersaring hingga menjadi air jernih (tanpa ada bahan atau zat pencampur yang banyak mempengaruhi kejernihan air).

Tahapan terakhir dalam pendekatan saintik yaitu mengkomunikasikan. Setelah siswa selesai menggunakan alat peraga dalam proses pemisahan campuran, maka siswa diwajibkan untuk menyampaikan hasil percobaan kepada teman-temannya di kelas. Hasil percobaan tentang pemisahan campuran dari masing-masing kelompok yang dipresentasikan kemudian ditanggapi oleh kelompok lain. Kegiatan ini mendukung munculnya sikap ilmiah terutama pada dimensi atau indikator rasa ingin tahu diantaranya yaitu antusias mencari jawaban, perhatian pada objek yang diamati, menanyakan setiap langkah kegiatan, serta antusias pada proses sains. Sehingga dapat dikatakan juga bahwa penggunaan alat peraga dalam pembelajaran IPA juga dapat meningkatkan pemahaman konsep materi pada siswa. Hal ini senada dengan hasil penelitian yang dilakukan oleh Apriliyanti, (2015: 840) bahwa penggunaan alat peraga dalam pembelajaran terbukti lebih memudahkan siswa dalam memahami materi, sebab siswa merasa lebih senang dan tertarik dengan pembelajaran menggunakan alat peraga.

\section{KESIMPULAN}

Berdasarkan hasil penelitian dan pembahasan, dapat disimpulkan bahwa pembelajaran IPA melalui pendekatan saintifik berbantuan alat peraga penjernihan air dapat diketahui sikap ilmiah dimensi rasa ingin tahu siswa meningkat.

Sedangkan saran yang dapat penulis berikan yaitu penggunaan alat peraga penjernihan air melalui pendekatan saintifik dapat dijadikan alternatif bagi guru pada materi pemisahan campuran. 


\section{DAFTAR PUSTAKA}

Apriliyanti, DS., Sri HAryani, \& Arif Widyatmoko. 2015. Pengembangan alat Peraga IPA Terpadu pada Tema Pemisahan Campuran untuk Meningkatkan Keterampilan Proses Sains. Unnes Science Education Journal. Vol.: 4. No 2. Hal 835-841.

Ismawati, F., Dwijananti, P., \& Nugroho, S. E. 2014. Penerapan Model Pembelajaran Conceptual Understanding Procedures Untuk Meningkatkan Curiosity dan Pemahaman Konsep Siswa. Jurnal Pendidikan Fisika Indonesia, 23.

Kosasih. 2014. Strategi Belajar dan Pembelajaran Implementasi Kurikulum 2013. Bandung: Yrama Widya.

Permendikbud. (2013). Jurnal Lampiran Peraturan Menteri Pendidikan dan Kebudayaan Republik Indonesia Nomor 65 Tahun 2013 Tentang Standar Proses Pendidikan Dasar dan Menengah.

Suciati, N., Arnyana, I., \& Setyawan, I. 2014. Pengaruh Model Pembelajaran Siklus Hipotetik Deduktif dengan Setting 7E Terhadap Hasil Belajar IPA Ditinjau Dari Sikap Ilmiah Siswa. e-Journal Program Pascasarjana Universitas Pendidikan Ganesha Program Studi IPA.

Sujarwanta, Agus. 2012. Mengkondisikan Pembelajaran IPA dengan Pendekatan Saintifik. Jurnal Nuansa Kependidikan. Vol. 16 No. 1. Hal 75-83.

Widiyatmoko, A., \& Pamelasari, S. D. 2012. Pengembangan Berbasis Proyek Untuk Mengembangkan Alat Peraga IPA Dengan Memanfaatkan Bahan Bekas Pakai. Jurnal Pendidikan IPA Indonesia. Vol: 1 No. 1. Hal 51-56.

Daryanto. 2014. Pendekatan Pembelajaran Saintifik Kurikulum 2013. Yogyakarta: Gava Media. 